\title{
Initial growth and yield structure of selected cultivars of cranberry (Vaccinium macrocarpon Ait.) cultivated on mineral soils
}

\author{
Eugeniusz Szwonek ${ }^{1 *}$, Robert Maciorowski ${ }^{1}$, Bohdan Koziński ${ }^{1}$, \\ Kazimierz Smolarz ${ }^{1}$, Lidia Sas-Paszt ${ }^{1}$, Hanna Bryk ${ }^{1}$, Edyta Derkowska ${ }^{1}$, \\ Estvan Estabrooks ${ }^{2}$ \\ ${ }^{1}$ Research Institute of Horticulture \\ Konstytucji 3 Maja 1/3, 96-100 Skierniewice, Poland \\ ${ }^{2}$ Evans \& Associates Agricultural Consulting \\ 207 Shaw Lane, New Maryland, NB, E3C 1J2, Canada
}

\begin{abstract}
A study was conducted to evaluate the possibility of cranberry cultivation on mineral soils and to assess the influence of vegetative biomass development, generative growth and yield components on the yielding of three cranberry cultivars originating in the USA (Stevens, Pilgrim and Ben Lear) at two locations in Poland. The key biometrical traits involved in yield formation were taken into account, and the soil and plant chemical conditions were evaluated. All of the measured biometrical characteristics were strongly influenced by the location and the year of cultivation, and varietal differences were also noted. The most important determinants that explained yield variation were: the number of uprights per square meter, floral induction and berry set. However, the participation of each component in yield variation was strongly affected by the location, age of plantation and to a minor extent by the cultivar. The study confirmed the possibility of cranberry cultivation on mineral soils with a low $\mathrm{pH}$. The biggest average yield of the three years was collected from cv. Stevens as cultivated on sandy soil in contrast to the same cultivar grown on sandy loam soil. In the case of sandy loam soil after acidification, cv. Pilgrim appeared to be a relatively better yielding cultivar.
\end{abstract}

Key words: component analysis, fruiting, interrelations, irrigation, soil $\mathrm{pH}$, vegetative biomass

\section{INTRODUCTION}

Cranberry is mainly grown in North America (U.S., Canada). It is also cultivated in Chile (Stang 1997) and New Zealand (Miller et al. 2009). The growing of cranberry has also been initiated in Latvia, Belarus, Romania, Azerbaijan and Tunisia (Food and Agriculture Organization - FAO of the United Nations 2012). Increasing knowledge about the specific properties of cranberry fruit, their health benefits and functional values (Howell et al. 2005, Howell 2009) that has been confirmed by conventional medical knowledge (Avorn et al. 1994, Shmuely et al. 2004, Vatten et al. 2005) has induced growth in demand for cranberries. In Central European countries, the cultivation of cranberry is still at a low level. Increasing market demand for these berries has stimulated the interest of Central European growers, who are expecting a satisfying income from the growing of this species. Till now, cranberry has been cultivated in Poland on several

\footnotetext{
*Corresponding author.

Tel.: +48 505026696; fax: +48 468333186

e-mail: Szwonek.Eugeniusz@inhort.pl (E. Szwonek).
} 
small parcels, not for commercial scale, on nonflooded or partially flooded plantations during the winter (Szwonek 2011, unpublished). Yield is the result of specific changes taking place in plants in subsequent phases of their development, as well as external factors that modify them. Thus, attention has been directed to carrying out diversified observations and biometric measurements that allow the evaluation of the relationship among the vegetative biomass growth, generative organs and fruiting in three cranberry cultivars grown in different soil conditions. Various statistical and biometrical methods were used to explain variation in cranberry yield, i.e. sequential yield component analysis on logarithmic data (Eaton and Kyte 1978), simple regression (Pelletier et al. 2015) and multiple regression (DeVetter et al. 2015). The objective of the presented work was to evaluate the possibility of cranberry cultivar cultivation in a non-flooding system on mineral soils of different $\mathrm{pH}$. In addition, the components involved in yield variation at the initial stage of plant growth (the first four growing seasons) were estimated.

\section{MATERIAL AND METHODS}

\section{Experimental sites and plant material}

The experiment was conducted under field conditions in two locations, Krojczyn and Kosuty, in the years 2011-2014. Three cranberry (Vaccinium macrocarpon Ait.) cultivars, Pilgrim, Stevens and Ben Lear, were cultivated. Rooted planting material was obtained by prior propagation of hardwood cuttings. The plantations were established on a flat area with one-year-old rooted cranberry plants, which were planted during the summer of 2011. The experimental design was a randomised block with three replications. The dimensions of each block were $10 \times 5 \mathrm{~m}$, i.e. $50 \mathrm{~m}^{2}$. The space between the rows was $0.5 \mathrm{~m}$ and $0.25 \mathrm{~m}$ between the plants in a row; a single block contained 400 plants of a given cultivar. Plants were grown under nonflooded conditions, but with overhead waterspraying of plants in Krojczyn (N52 $41^{\prime}$; E19 ${ }^{\circ} 12^{\prime}$ ), on a sandy soil with a $\mathrm{pH}$ of 3.6-3.7, and in Kosuty (N51 ${ }^{\circ} 52^{\prime} ;$ E22 $\left.2^{\circ} 09^{\prime}\right)$ under less favourable soil conditions, i.e. sandy-loam soil of $\mathrm{pH} 7.3$, which was adjusted to $\mathrm{pH} 5.2$ by means of $60 \% \mathrm{HNO}_{3}$.

\section{Irrigation}

Up-to-date measurements of soil moisture were performed using a Takemura DM-15 Soil Tester. The use of sprinklers during the growing season was dependent on natural rainfall and the moisture of topsoil. Watering was applied when the field soil water capacity as indicated by the mentioned tester had dropped down below $10-20 \%$ on the sandy soil and $30-40 \%$ on the sandy-loam soil. The dose of water was on average $15-20 \mathrm{~mm}$. In the case of plants grown on sandy loam soil in Kosuty, acidified water was temporarily applied, i.e. twothree times at the beginning and/or at the end of each growing season. In this case, the water was acidified by diluting $600 \mathrm{~cm}^{3}$ of $60 \% \mathrm{HNO}_{3}$ with $30 \mathrm{dm}^{3}$ of water, and then again diluted with water which was supplied via the watering system at an irrigation dose equivalent to $15-20 \mathrm{~mm}$.

\section{Fertilization and fertilization rates}

The following fertilizers were used as top dressing: ammonium sulphate (N) $28.8 \%$, (S) 24\%, triple superphosphate (P) 20\%, (S) $2 \%$ and potassium sulphate (K) 41.5\%, (S) 18\%. Ammonium sulphate and potassium sulphate were applied in April/ May 2012-2014 and superphosphate in the middle of October 2011 and 2013. The doses of mineral nutrients in respective fertilizer applications were as follows: ammonium sulphate $32 \mathrm{~kg} \mathrm{~N}^{-1}$ and $27 \mathrm{~kg} \mathrm{~S} \mathrm{ha}^{-1}$, and potassium sulphate $46 \mathrm{~kg} \mathrm{~K} \mathrm{ha}^{-1}$ and $20 \mathrm{~kg} \mathrm{~S}^{-1}$, triple superphosphate $22 \mathrm{~kg} \mathrm{P} \mathrm{ha}^{-1}$ and $2.2 \mathrm{~kg} \mathrm{Sha}^{-1}$.

\section{Analysis of soil and plant samples}

Soil organic matter, total salt concentration and nutrient content in the upper soil horizon were determined for each year and location. For $\mathrm{pH}_{1 \mathrm{Mol} \mathrm{KCl}}$ and soil salinity evaluation, an electrochemical procedure was applied using the ACCUMET Fisher Scientific pH/Conductometer. Phosphorus and potassium content was extracted from the soil using the Egner-Riehm method (calcium lactate $\mathrm{pH} 3.5$ soil extraction), magnesium using the Schachtschabel method (calcium chloride $0.025 \mathrm{~N}$ soil extraction), calcium extraction with $1 \mathrm{~N}$ ammonium acetate, sulphur with $0.25 \mathrm{Mol} / 1$ acetic acid and ammonium acetate, and then determined with an emission spectrophotometer with ion coupled plasma ICP-OES using the Thermo Scientific iCAP 6000 series. The amounts of total nitrogen and organic carbon in the soil samples were analysed with a LECO TruSpec CNS analyser. Chemical analyses of cranberry tissue were performed on leaves annually picked from 20-30 runners on the appropriate plots of cranberry cultivars in Krojczyn and Kosuty. N content according to Dumas was determined using the conductivity method. The amounts of phosphorus, potassium, magnesium and calcium in plant 
samples were determined after their microwave wet digestion (5:1 solution of $65 \% \mathrm{HNO}_{3}+30 \% \mathrm{H}_{2} \mathrm{O}_{2}$ ) by atomic inductively coupled absorption ICP-OES using the Thermo Scientific iCAP 6000 series. Analyses of soil and plant samples were performed in the Analytical Laboratory accredited No. AB 363 at the Research Institute of Horticulture in Skierniewice.

\section{Measurement of plant growth, yield and yield components}

The vegetative growth of plants $(G P)$ was evaluated visually on a ranking scale from 1 (weak growth) to 5 (strong growth) at the end of each growing season. In the first year of the study, the runner i.e. runners shoot length $(R L)$ and the number of runners per plant $(N R / P)$ as well as per surface area $\left(N R / \mathrm{m}^{2}\right)$ were determined, while in the subsequent years (because of the strong mutual shoot overgrowth) these were evaluated as the percentage coverage $(P C)$ of the plot's surface area by the shoots. This was done by using a $1 \mathrm{~m}^{2}$ measuring frame, and placing it randomly in five places on every plot of each cultivar. The same method was used to measure the number of uprights (vertical shoots) per $\mathrm{m}^{2}\left(\mathrm{NU} / \mathrm{m}^{2}\right)$, number of flowering uprights per $\mathrm{m}^{2}\left(N F U / \mathrm{m}^{2}\right)$, floral induction $(F I)-N F U / \mathrm{m}^{2} / \mathrm{NU} /$ $m^{2}$, number of flowers per uprights $(N F / U)$ and number of flowers per $\mathrm{m}^{2}\left(N F / m^{2}\right)-N F / U \times N F U /$ $m^{2}$. Individual berry weight $(B W)$ was calculated as the weight of 100 berries. Yield (mass of harvested berries) was measured separately for each plot. On the basis of Yield and $B W$, the number of berries per $\mathrm{m}^{2}\left(N B / m^{2}\right)-$ Yield $/ B W$, and fruit set $(B S)-N B / m^{2}$ : $N F / m^{2}$ were estimated.

\section{Statistical data analysis}

The collected data have a typical repeated-measure structure, in which multiple measurements were made on the same plot across time (three or two years) at each location.

The basic liner mixed model represents the trait value $y_{i j k l}$ for the $j$ th variety $V_{J}$ at the $k$ th year $Y_{k}$ and $l$ th location $L_{l}$ in the $i$ th block as: $y_{i j k}=\beta_{0}+$ $\beta_{l} V_{j}+\beta_{2} Y_{k}+\beta_{3} L_{l}+\beta_{4} V_{j} \times Y_{k}+\beta_{5} V_{j} \times L_{l}+\beta_{6} Y_{k} \times$ $L_{l}+\beta_{7} V_{j} \times Y_{k} \times L_{l}+b_{i}+b_{i j k l}+\varepsilon_{i j k}$, where: $i=1$, $\ldots, 3 ; j=1, \ldots, 3 ; k=1,2$ or $3 ; l=1, \ldots 2$. The fixed intercept $\beta_{0}$ represents the expected value of trait $y_{i k k l}$. The parameters $\beta_{p}, \ldots, \beta_{7}$, represent the fixed effects of the Variety (Cultivar), Year, Location and their interaction, respectively. The $b_{i}$ denote the Block random effects, the $b_{\mathrm{ijk}}$ denote the Variety (Cultivar) within Block at each Year and Locations random effects, and the $\varepsilon_{i j k}$ denote errors. In the first step of parameter estimation (REML estimation method), the basic model had a compound symmetry structure: equal variances at all $Y_{k}$ at $L_{l}$ and equal covariance between measurements on the same plot at all pairs of $Y_{k}$ at $L_{l}$. On the basis of the information criterions (Akaike, Bayesian) and $L R T$ test, the best-fitting variance structure was a first-order autoregressive covariance structure and was incorporated into the basic model at the finish point. The model estimation was done by means of a 'nlme' package (v. 3.1-120) with function 'Ime' (Pinheiro and Bates 2000) in the R statistical environment (R Development Core Team 2015). The fixed parameter vectors and covariance matrix produced by 'nlme' were used in a 'multcomp' package v. 1.4-0 (Bretz et al. 2011) with function 'glht' (Tukey type procedure) to compare means for the significant effects of the model.

The method proposed by Piepho (1995) was used to quantify the respective contributions of cranberry yield components to the yield variability caused by cultivar, year, location and interaction of all of them. The cranberry yield may be regarded as the end point of the process of which the successive stages are represented by the following components: Yield $=N U / m^{2} \times F I \times N F / U \times B S \times B W$.

The logarithm (log) transformation of this equation expressed log yield as the sum of the logs of its components. These log components should be independent of each other and their variances should add up to the variance of the $\log$ of the yield. However, they are not independent; the covariances between all $\log$ components must be taken into account in $\log$ yield variability. The contribution of each log component to the variance of the $\log$ yield can then be written as:

$$
c_{i}=\sigma_{i}^{2}+\sum_{j \neq i} \sigma_{i j}
$$

where: $c_{i}$ - the contribution of the ${ }_{i}$ th yield component, $\sigma_{i}^{2}-$ the variance of the $\log$ th component and the $\sigma_{i j}$ - co-variances between the th $\log$ component and the other log components. The variances and covariances were estimated for using a 'mlmmm' package (v. 0.3-1.2) with the function 'mlmmm.em' (Schafer and Yucel 2002). Maximum likelihood estimators of a multivariate linear mixed model have been used on the logarithms of five cranberry yield components because of nonorthogonal data. The model in simple notation is: $Y=X \beta+Z b+e$, where: $Y-$ a matrix of the five yield components, $X$ - a matrix of the fixed elements of the model (Cultivar, Year and Location), $Z-$ 
a matrix of random elements of the model (Block), $\beta$ - a matrix of fixed parameters, $b-$ a matrix of random parameters and $e-$ a matrix of residual errors.

\section{RESULTS}

\section{Soil chemical properties and nutrient content in plants}

In the conducted experiment, plants were grown on two different mineral soils differentiated by their physical as well as chemical properties (Tab. 1). The properties of the soil of the two fields clearly differed in respect to $\mathrm{pH}$, mineral content, organic matter content and salinity. The soil chemical properties did not change considerably during the experiment, except for the soil pH in Kosuty (Tab. 1). The mean amounts of minerals in leaf tissue samples taken in 2011-2014 from plants in Krojczyn were: $1.4 \mathrm{~N}$, 0.15 P, $0.7 \mathrm{~K}, 0.18 \mathrm{Mg}, 0.6 \mathrm{Ca}, 0.18 \mathrm{~S}$, [\% d.m.]; 27.2 $\mathrm{B}, 3.7 \mathrm{Cu}, 14.2 \mathrm{Zn}\left[\mathrm{mg} \mathrm{kg}^{-1}\right.$ d.m.], and in Kosuty: $1.1 \mathrm{~N}, 0.1 \mathrm{P}, 0.6 \mathrm{~K}, 0.1 \mathrm{Mg}, 0.8 \mathrm{Ca}, 0.1 \mathrm{~S}$ [\% d.m.], 34.2 B, 2.8 Cu, $22.9 \mathrm{Zn}\left[\mathrm{mg} \mathrm{kg}^{-1} \mathrm{~d}\right.$.m.]. The different locations of the trial fields stemmed from the intention to assess the indicators of cranberry plants grown in different soil conditions and more diverse weather situations. The properties of the soil of the fields differed significantly in respect to $\mathrm{pH}$, as reported by Davenport et al. (2003). Additionally, the $\mathrm{pH}$ of the upper soil layer in Kosuty was 7.3 at the beginning and then was lowered by acidification to 5.2. In both fields, the amounts of nutrients in the soil and also the mineral contents in the plants met the requirements for the growth and fruiting of cranberry plants as indicated by the results given by Poole et al. (1997).

\section{Vegetative biomass}

The growth and development of plants began to diversify soon after the planting of cuttings. At the end of the 2011 growing season, the biometric measurements - NR/P, RL, and $N R / m^{2}-$ were affected by the location and the cultivar, and also by the interaction of the two (Tab. 2). The plants of 'Ben Lear' produced a relatively lower number of new runners than those of 'Pilgrim' and 'Stevens'

Table 1. Chemical properties of the upper layer of soil in Krojczyn and Kosuty (2011-2014)

\begin{tabular}{|c|c|c|c|c|c|c|c|c|}
\hline \multirow{2}{*}{ Indicators } & \multicolumn{4}{|c|}{ Krojczyn } & \multicolumn{4}{|c|}{ Kosuty } \\
\hline & 2011 & 2012 & 2013 & 2014 & 2011 & 2012 & 2013 & 2014 \\
\hline $\mathrm{pH}_{\mathrm{KCl}}$ & 3.7 & 3.6 & 3.7 & 3.7 & 7.3 & 5.2 & 5.2 & 5.4 \\
\hline Salinity $\left(\mathrm{KCl}\left[\mathrm{g} \mathrm{kg}^{-1}\right]\right)$ & $<0.1$ & 0.1 & 0.1 & 0.3 & 0.4 & 0.3 & 0.4 & 0.4 \\
\hline Organic matter [\% d.m.] & 1.0 & 1.0 & 1.0 & 1.2 & 1.8 & 2.8 & 1.7 & 2.3 \\
\hline $\mathrm{C}[\%$ d.m. $]$ & 0.56 & 0.59 & 0.57 & 0.72 & 1.03 & 1.03 & 1.02 & 1.31 \\
\hline $\mathrm{N}$ [\% d.m.] & 0.06 & 0.06 & 0.05 & 0.04 & 0.11 & 0.10 & 0.11 & 0.08 \\
\hline $\mathrm{P}\left[\mathrm{mg} 100 \mathrm{~g}^{-1}\right]$ & 9.8 & 9.6 & 7.2 & 8.8 & 12.1 & 9.7 & 10.1 & 9.7 \\
\hline $\mathrm{K}\left[\mathrm{mg} 100 \mathrm{~g}^{-1}\right]$ & 1.4 & 2.9 & 3.2 & 6.7 & 11.5 & 10.3 & 8.3 & 8.5 \\
\hline $\mathrm{Mg}\left[\mathrm{mg} 100 \mathrm{~g}^{-1}\right]$ & 0.3 & 0.7 & 1.5 & 1.5 & 7.0 & 4.6 & 3.8 & 3.4 \\
\hline $\mathrm{Ca}\left[\mathrm{mg} 100 \mathrm{~g}^{-1}\right]$ & 3.8 & 3.3 & 4.6 & 3.3 & 11.5 & 5.0 & 6.7 & 7.6 \\
\hline $\mathrm{SO}_{4}\left[\mathrm{mg} 100 \mathrm{~g}^{-1}\right]$ & 1.1 & 2.4 & 1.2 & 1.7 & 6.4 & 1.6 & 1.9 & 5.2 \\
\hline
\end{tabular}

Table 2. The results of ANOVA of the linear mixed model for estimated traits and tested fixed effects

\begin{tabular}{|c|c|c|c|c|c|c|c|c|c|c|c|c|c|c|}
\hline Effect & Yield & $\sum$ Yield & $\mathrm{NU} / \mathrm{m}^{2}$ & $F I$ & $\mathrm{NFU} / \mathrm{m}^{2}$ & $N F / U$ & $N F / m^{2}$ & $B S$ & $N B / m^{2}$ & $B W$ & $R L$ & $N R / P$ & $G P$ & $P C$ \\
\hline Year (Y) & $* * *$ & - & $* * *$ & $* * *$ & $* * *$ & NS & $* * *$ & $* * *$ & $* * *$ & $* * *$ & - & - & $* * *$ & $* * *$ \\
\hline Location (L) & $* * *$ & $* * *$ & $* * *$ & $* * *$ & $* * *$ & $* * *$ & $* * *$ & $* * *$ & $* * *$ & $* * *$ & $* * *$ & $* * *$ & $* * *$ & $* * *$ \\
\hline Cultivar (C) & $* * *$ & $* *$ & $* * *$ & $* * *$ & $* * *$ & $*$ & $* * *$ & NS & $* * *$ & $* * *$ & $* * *$ & $* * *$ & $*$ & $* * *$ \\
\hline $\mathrm{Y} \times \mathrm{L}$ & $* * *$ & - & $* * *$ & $* * *$ & $* * *$ & $* *$ & $* * *$ & $*$ & $* * *$ & $* * *$ & - & - & $* * *$ & $* * *$ \\
\hline $\mathrm{Y} \times \mathrm{C}$ & $* *$ & - & $* *$ & $*$ & NS & $\mathrm{NS}$ & $* * *$ & NS & $*$ & $* * *$ & - & - & NS & NS \\
\hline $\mathrm{L} \times \mathrm{C}$ & $* * *$ & $* *$ & $* * *$ & * & $* *$ & NS & $* * *$ & NS & $* * *$ & $* * *$ & $* * *$ & $* * *$ & $*$ & NS \\
\hline $\mathrm{Y} \times \mathrm{L} \times \mathrm{C}$ & $* * *$ & - & $* * *$ & $* * *$ & NS & NS & $*$ & NS & $*$ & $* * *$ & - & - & NS & * \\
\hline
\end{tabular}

${ }^{*} \mathrm{p} \leq 0.05 ; * * \mathrm{p} \leq 0.01 ; * * \mathrm{p} \leq 0.001 ; \mathrm{NS}-\mathrm{p}>0.05 . N F / m^{2}-$ number of flowers per square meter; $F I-$ flowering index $\left(N F U / m^{2}\right.$ $\left.: N U / \mathrm{m}^{2}\right) ; N F U / \mathrm{m}^{2}$ - number of flowering uprights per square meter; $N F / U$ - number of flowers per upright; $N F / \mathrm{m}^{2}$ - number of flowers per square meter; $B S$ - fruit set $\left(\mathrm{NB} / \mathrm{m}^{2}: \mathrm{NF} / \mathrm{m}^{2}\right) ; \mathrm{NB} / \mathrm{m}^{2}$ - number of berries per square meter; $B W$ - individual berry weight; $R L$ - average single runner length; $N R / P$ - number of runners per plant; $G P$ - growth power (ranged 1-5); $P C$ - soil surface covering by plants $(\%)$ 
Table 3. Initial growth of cranberry plants depending on the cultivar in Krojczyn and Kosuty in the first growing season $(2011 / 2012)$

\begin{tabular}{lcccccc}
\hline \multirow{2}{*}{ Indicators } & \multicolumn{3}{c}{ Krojczyn } & \multicolumn{3}{c}{ Kosuty } \\
\cline { 2 - 7 } & Pilgrim & Stevens & Ben Lear & Pilgrim & Stevens & Ben Lear \\
\hline$N R / P$ & $5.3 \mathrm{a}$ & $4.7 \mathrm{~b}$ & $4.5 \mathrm{~b}$ & $4.7 \mathrm{a}$ & $5.0 \mathrm{a}$ & $3.0 \mathrm{~b}$ \\
$R L[\mathrm{~cm}]$ & $78 \mathrm{a}$ & $52 \mathrm{~b}$ & $48 \mathrm{~b}$ & $84 \mathrm{a}$ & $91 \mathrm{a}$ & $54 \mathrm{~b}$ \\
$N R / m^{2}$ & $37.1 \mathrm{a}$ & $34.7 \mathrm{a}$ & $30.5 \mathrm{~b}$ & $34.6 \mathrm{a}$ & $40.0 \mathrm{a}$ & $23.8 \mathrm{c}$ \\
Plants lost [\%] & 29.5 & 21.8 & 29.4 & 20.2 & 18.2 & 25.5 \\
\hline
\end{tabular}

Values in the column for each location and trial marked with the same letter do not differ significantly at $\mathrm{p}=0.05 . N R / P-$ number of runners per plant; $R L$ - average single runner length; $N R / \mathrm{m}^{2}$ - number of runners per $\mathrm{m}^{2}$ of soil surface; Plants lost - share of plants lost after winter 2011/2012

Table 4. Advanced growth of cranberry plants in Krojczyn and Kosuty (2012-2014)

\begin{tabular}{llcccccc}
\hline \multirow{2}{*}{ Indicators } & Cultivar & \multicolumn{3}{c}{ Krojczyn } & \multicolumn{4}{c}{ Kosuty } \\
\cline { 2 - 8 } & & 2012 & 2013 & 2014 & 2012 & 2013 & 2014 \\
\hline \multirow{3}{*}{$P C[\%]$} & Pilgrim & $35 \mathrm{a}$ & $72 \mathrm{a}$ & $92 \mathrm{a}$ & $15 \mathrm{a}$ & $40 \mathrm{a}$ & $67 \mathrm{a}$ \\
& Stevens & $35 \mathrm{a}$ & $77 \mathrm{a}$ & $85 \mathrm{~b}$ & $14 \mathrm{a}$ & $33 \mathrm{~b}$ & $63 \mathrm{a}$ \\
& Ben Lear & $32 \mathrm{a}$ & $75 \mathrm{a}$ & $87 \mathrm{ab}$ & $10 \mathrm{a}$ & $27 \mathrm{c}$ & $53 \mathrm{~b}$ \\
\hline \multirow{3}{*}{$G P$} & Pilgrim & $4.0 \mathrm{a}$ & $4.2 \mathrm{a}$ & $4.3 \mathrm{a}$ & $2.2 \mathrm{a}$ & $4.0 \mathrm{a}$ & $4.3 \mathrm{a}$ \\
& Stevens & $4.2 \mathrm{a}$ & $4.7 \mathrm{a}$ & $4.2 \mathrm{a}$ & $2.5 \mathrm{a}$ & $3.5 \mathrm{a}$ & $4.3 \mathrm{a}$ \\
& Ben Lear & $4.2 \mathrm{a}$ & $4.5 \mathrm{a}$ & $4.3 \mathrm{a}$ & $1.7 \mathrm{a}$ & $2.8 \mathrm{a}$ & $4.3 \mathrm{a}$ \\
\hline
\end{tabular}

Values in the column for each trait marked with the same letter do not differ significantly at $\mathrm{p}=0.05$. $P C$ - soil surface covering by plants; $G P$ - growth power (ranged 1-5)

(Tab. 3). Although the differences in $N R / P$ were rather small on both plantations, the young plants in Krojczyn produced slightly more shoots. The shortest runners $(R L)$ were produced by the plants cultivated in Kosuty, and mostly in the case of the plants of 'Ben Lear'. In both experiments, the fewest shoots grew from the cuttings of 'Ben Lear'. After the first winter, the number of lost plants was higher among the plants in Krojczyn. In both locations, the plants of 'Stevens' survived the winter better, whereas those of 'Ben Lear' were comparatively the worst affected. In the following year, the largest biomass $(G P)$ was also produced by the cranberry plants in Krojczyn (Tabs 2 and 4). However, in the following years the differences between plants in the two locations decreased. The evaluation of the extent of coverage of the soil by cranberry plants $(P C)$ indicated that the plants in the experiment in Krojczyn were better developed than in Kosuty. The coverage of the soil surface with the shoots of plants in Kosuty improved in consecutive years, but it was still smaller than in Krojczyn.

\section{Generative growth}

The traits representing upright production $\left(N U / m^{2}\right)$ and flowering $\left(F I, N F / \mathrm{m}^{2}\right)$, and combinations of them $\left(N F / U, N F U / m^{2}\right)$, differed significantly depending on the location, year of growth, cultivars and their interaction (Tab. 2). The generative potential of the plants was a consequence of their vegetative growth. In the spring of 2012, the first uprights appeared on the plants in Krojczyn. During the same season, practically no uprights grew out of the runners in Kosuty and thus there was no blossom there. In 2013, flowering in Kosuty improved, but decreased again in 2014, both in Krojczyn and Kosuty. The values of $N U / \mathrm{m}^{2}, N F U / \mathrm{m}^{2}$ and $F I$ fluctuated from year to year (Tab. 5). On average, the cranberry plants in Krojczyn formed more $\mathrm{NU} / \mathrm{m}^{2}$ and had greater $\mathrm{FI}$ than those in Kosuty, and consequently had higher $N F / m^{2}$. In Krojczyn, the cultivars Stevens and Pilgrim had similar FI and $N F / m^{2}$, which were greater than those of 'Ben Lear', whereas in Kosuty, the cultivar Pilgrim dominated in terms of higher $N U / m^{2}$ and $N F U / m^{2}$.

\section{Yielding}

Fruit set $(B S)$ fluctuated over the years of the experiment mainly in Krojczyn and on average was greater in that location than in Kosuty. Individual berry weight $(B W)$ was the most stable trait across the years in each location. Except for the year 2014, 'Pilgrim' cranberry plants produced larger berries than the other cultivars. The value of $N B / m^{2}$ was higher in Krojczyn than in Kosuty. 'Stevens' produced significantly more berries per $\mathrm{m}^{2}$ in Krojczyn compared with the other cultivars, whereas in Kosuty 'Pilgrim' significantly surpassed 
Table 5. Generative development of cranberry plants in Krojczyn and Kosuty (2012-214)

\begin{tabular}{|c|c|c|c|c|c|c|c|c|}
\hline \multirow{2}{*}{ Indicators } & \multirow{2}{*}{ Cultivar } & \multicolumn{4}{|c|}{ Krojczyn } & \multicolumn{3}{|c|}{ Kosuty } \\
\hline & & 2012 & 2013 & 2014 & Mean & 2013 & 2014 & Mean \\
\hline \multirow{3}{*}{$N U / m^{2}$} & Pilgrim & $73 \mathrm{a}$ & $573 \mathrm{c}$ & $752 \mathrm{~b}$ & $488 \mathrm{~b}$ & $542 \mathrm{a}$ & $310 \mathrm{a}$ & $426 \mathrm{a}$ \\
\hline & Stevens & $85 \mathrm{a}$ & $650 \mathrm{~b}$ & $1090 \mathrm{a}$ & $608 \mathrm{a}$ & $417 \mathrm{~b}$ & $173 \mathrm{~b}$ & $295 \mathrm{~b}$ \\
\hline & Ben Lear & $93 a$ & $732 \mathrm{a}$ & $673 \mathrm{c}$ & $499 \mathrm{~b}$ & $277 \mathrm{c}$ & $200 \mathrm{~b}$ & $238 \mathrm{~b}$ \\
\hline \multirow{3}{*}{$N F U / m^{2}$} & Pilgrim & $18 \mathrm{a}$ & $445 \mathrm{a}$ & $192 \mathrm{a}$ & $218 \mathrm{a}$ & $125 \mathrm{a}$ & $92 \mathrm{a}$ & $108 \mathrm{a}$ \\
\hline & Stevens & $13 \mathrm{a}$ & $485 \mathrm{a}$ & $273 \mathrm{a}$ & $257 \mathrm{a}$ & $93 \mathrm{a}$ & $72 \mathrm{a}$ & $82 \mathrm{a}$ \\
\hline & Ben Lear & $12 \mathrm{a}$ & $322 \mathrm{a}$ & $155 \mathrm{a}$ & $274 \mathrm{a}$ & $67 \mathrm{a}$ & $53 \mathrm{a}$ & $60 \mathrm{a}$ \\
\hline \multirow{3}{*}{$N F / m^{2}$} & Pilgrim & $71 \mathrm{a}$ & $2068 \mathrm{~b}$ & 992 b & $1044 \mathrm{a}$ & $502 \mathrm{a}$ & $330 \mathrm{a}$ & $416 \mathrm{a}$ \\
\hline & Stevens & $54 \mathrm{a}$ & $2262 \mathrm{a}$ & $1168 \mathrm{a}$ & $1156 \mathrm{a}$ & $388 \mathrm{ab}$ & $203 \mathrm{a}$ & $296 b$ \\
\hline & Ben Lear & $37 \mathrm{a}$ & $1177 \mathrm{c}$ & $755 \mathrm{c}$ & $662 \mathrm{~b}$ & $244 \mathrm{~b}$ & $163 \mathrm{a}$ & $204 \mathrm{~b}$ \\
\hline \multirow{3}{*}{$N F / U$} & Pilgrim & $3.8 \mathrm{a}$ & $4.7 \mathrm{a}$ & $5.2 \mathrm{a}$ & $4.6 \mathrm{a}$ & $4.0 \mathrm{a}$ & $3.7 \mathrm{a}$ & $3.8 \mathrm{a}$ \\
\hline & Stevens & $4.0 \mathrm{a}$ & $4.7 \mathrm{a}$ & $4.3 \mathrm{a}$ & $4.3 \mathrm{a}$ & $4.1 \mathrm{a}$ & $2.9 \mathrm{a}$ & $3.5 \mathrm{a}$ \\
\hline & Ben Lear & $3.2 \mathrm{a}$ & $3.7 \mathrm{a}$ & $4.9 \mathrm{a}$ & $3.9 \mathrm{a}$ & $3.7 \mathrm{a}$ & $3.0 \mathrm{a}$ & $3.4 \mathrm{a}$ \\
\hline \multirow{3}{*}{$F I$} & Pilgrim & $0.25 \mathrm{a}$ & $0.77 \mathrm{a}$ & $0.26 \mathrm{a}$ & $0.42 \mathrm{a}$ & $0.23 \mathrm{a}$ & $0.30 \mathrm{~b}$ & $0.26 \mathrm{a}$ \\
\hline & Stevens & $0.16 \mathrm{~b}$ & $0.74 \mathrm{a}$ & $0.25 \mathrm{a}$ & $0.38 \mathrm{a}$ & $0.22 \mathrm{a}$ & $0.44 \mathrm{a}$ & $0.33 \mathrm{a}$ \\
\hline & Ben Lear & $0.12 \mathrm{~b}$ & $0.44 \mathrm{~b}$ & $0.23 \mathrm{a}$ & $0.26 \mathrm{~b}$ & $0.24 \mathrm{a}$ & $0.28 \mathrm{~b}$ & $0.26 \mathrm{a}$ \\
\hline
\end{tabular}

Values in the column for each trait marked with the same letter do not differ significantly at $\mathrm{p}=0.05 . \mathrm{NU} / \mathrm{m}^{2}-$ number of uprights per square meter; $N F U / m^{2}$ - number of flowering uprights per square meter; $\mathrm{NF} / \mathrm{m}^{2}$ - number of flowers per square meter; $N F / U-$ number of flowers per upright; $\mathrm{FI}$ - flowering index $\left(\mathrm{NFU} / \mathrm{m}^{2}: \mathrm{NU} / \mathrm{m}^{2}\right)$

the other cultivars in this trait. Fruit yield changed significantly over the years of the experiment in each location. On average, in Krojczyn 'Stevens' yielded higher than the other cultivars, whereas in Kosuty the best-yielding cultivar was Pilgrim. The yield of berries in Krojczyn was almost four times greater than that in Kosuty (Tab. 6).

\section{DISCUSSION}

In Massachusetts, USA, cranberry (Vaccinium macrocarpon Ait.) bogs, which were historically developed on existing wetlands, are now being established in new mineral soils that have been converted into artificial wetlands (DeMoranville 2006). In North America, cranberries are commonly cultivated on boggy or marshy soils. According to Davenport and DeMoranville (1993), the soils used in cranberry cultivation are within a wide range, i.e. from pure sands to pure peat, with a wide range of organic matter content. In Chile, commercial plantations of cranberries are grown on volcanic ash, with the needs of the plants adapted to the

Table 6. Yielding of cranberry plants in Krojczyn and Kosuty (2012-2014)

\begin{tabular}{|c|c|c|c|c|c|c|c|c|}
\hline \multirow{2}{*}{ Indicators } & \multirow{2}{*}{ Cultivar } & \multicolumn{4}{|c|}{ Krojczyn } & \multicolumn{3}{|c|}{ Kosuty } \\
\hline & & 2012 & 2013 & 2014 & Mean & 2013 & 2014 & Mean \\
\hline \multirow{3}{*}{$B S$} & Pilgrim & $0.13 \mathrm{a}$ & $0.10 \mathrm{a}$ & $0.25 \mathrm{a}$ & $0.16 \mathrm{a}$ & $0.04 \mathrm{a}$ & $0.13 \mathrm{a}$ & $0.09 \mathrm{a}$ \\
\hline & Stevens & $0.11 \mathrm{a}$ & $0.10 \mathrm{a}$ & $0.26 \mathrm{a}$ & $0.17 \mathrm{a}$ & $0.04 \mathrm{a}$ & $0.04 \mathrm{~b}$ & $0.04 \mathrm{a}$ \\
\hline & Ben Lear & $0.35 \mathrm{a}$ & $0.11 \mathrm{a}$ & $0.28 \mathrm{a}$ & $0.25 \mathrm{a}$ & $0.07 \mathrm{a}$ & $0.04 \mathrm{~b}$ & $0.06 \mathrm{a}$ \\
\hline \multirow{3}{*}{$N B / m^{2}$} & Pilgrim & $10 \mathrm{a}$ & $203 a$ & $68 \mathrm{~b}$ & $94 \mathrm{~b}$ & $18 \mathrm{a}$ & $39 a$ & $29 a$ \\
\hline & Stevens & $6 \mathrm{a}$ & $218 \mathrm{a}$ & $189 \mathrm{a}$ & $138 \mathrm{a}$ & $16 \mathrm{a}$ & $7 \mathrm{~b}$ & $12 \mathrm{~b}$ \\
\hline & Ben Lear & $13 \mathrm{a}$ & $126 \mathrm{~b}$ & $81 \mathrm{~b}$ & $73 \mathrm{c}$ & $18 \mathrm{a}$ & $7 \mathrm{~b}$ & $13 \mathrm{~b}$ \\
\hline \multirow{3}{*}{$B W[\mathrm{~g}]$} & Pilgrim & $1.96 \mathrm{a}$ & $2.05 \mathrm{a}$ & $2.06 \mathrm{~b}$ & $2.02 \mathrm{a}$ & $1.87 \mathrm{a}$ & $1.81 \mathrm{ab}$ & $1.84 \mathrm{a}$ \\
\hline & Stevens & $1.63 \mathrm{~b}$ & $1.49 \mathrm{c}$ & $2.16 \mathrm{ab}$ & $1.76 \mathrm{~b}$ & $1.68 \mathrm{~b}$ & $1.74 \mathrm{~b}$ & $1.71 \mathrm{a}$ \\
\hline & Ben Lear & $1.69 \mathrm{~b}$ & $1.84 \mathrm{~b}$ & $2.21 \mathrm{a}$ & $1.91 \mathrm{a}$ & $1.62 \mathrm{~b}$ & $1.93 \mathrm{a}$ & $1.78 \mathrm{a}$ \\
\hline \multirow{3}{*}{ Yield $\left[\mathrm{kg} 100 \mathrm{~m}^{-2}\right]$} & Pilgrim & $2.1 \mathrm{a}$ & $41.4 \mathrm{a}$ & $14.0 \mathrm{c}$ & $19.2 \mathrm{~b}$ & $3.3 \mathrm{a}$ & $7.1 \mathrm{a}$ & $5.2 \mathrm{a}$ \\
\hline & Stevens & $1.0 \mathrm{a}$ & $32.5 \mathrm{~b}$ & $40.7 \mathrm{a}$ & $24.7 \mathrm{a}$ & $2.7 \mathrm{a}$ & $1.3 \mathrm{~b}$ & $2.0 \mathrm{~b}$ \\
\hline & Ben Lear & $2.1 \mathrm{a}$ & $23.2 \mathrm{c}$ & $18.0 \mathrm{~b}$ & $14.4 \mathrm{c}$ & $2.9 \mathrm{a}$ & $1.3 \mathrm{~b}$ & $2.1 \mathrm{~b}$ \\
\hline
\end{tabular}

Values in the column for each trait marked with the same letter do not differ significantly at $\mathrm{p}=0.05 . B S-$ fruit set $\left(N B / \mathrm{m}^{2}: N F / \mathrm{m}^{2}\right)$; $\mathrm{NB} / \mathrm{m}^{2}$ - number of berries per square meter; $B W$ - individual berry weight; Yield -yield of berries [kg $\left.100 \mathrm{~m}^{-2}\right]$ 
requirements of growth and fruiting (Stang 1997). The possibility of growing cranberries on mineral soil in Poland has been reported by Karczmarczyk and Zbieć (1998a,b), Benedycka et al. (2005), Krzewińska et al. (2008) and Kaczmarska (2009).

In our case, plants were grown on two different mineral soils differentiated by their physical as well as their chemical properties (Tab. 1). The different locations of the trial fields stemmed from the intention to assess the indicators of cranberry plants grown in different soil conditions and more diverse weather situations. The properties of the soil in the fields differed significantly in respect to $\mathrm{pH}$, as reported by Davenport et al. (2003). Additionally, the $\mathrm{pH}$ of the upper soil layer in Kosuty was 7.3 at the beginning and then was lowered by acidification to 5.2. In both fields, the amounts of nutrients in the soil as well as the mineral contents in the plants met the requirements for the growth and fruiting of cranberry plants as indicated by the results given by Poole et al. (1997). All of the parameters of vegetative biomass growth indicated that the three cultivars of cranberry grew most dynamically on sandy soil with a $\mathrm{pH}$ of 3.7. Evaluation of the growth of cranberry plants in the spring of 2012 showed that their development in Kosuty was slower. This suggests that the slower growth of plants in Kosuty compared with Krojczyn was most of all caused by the higher soil $\mathrm{pH}$ during planting $(\mathrm{pH} \sim 7.3)$. The growth of plants in Kosuty improved, however, in the following two years after soil acidification to $\mathrm{pH} \sim 5$, as indicated by the covering of the soil surface with plants, and their growth vigour, too. Thus, the impact of environmental conditions on vegetative biomass appeared very significant already in the initial period of plant proliferation. At that time, this appeared to be a very clear response of cranberry cultivars to the growing conditions. The reproductive phase in plants generally follows the formation of an appropriate amount of vegetative biomass. In the case of cranberries, it is the horizontal expansion of runners, followed by the growth of shorter uprights (Van den Heuvel and DeMoranville 2009). The development of the reproductive organs of plants, like the preceding development of vegetative biomass, was also more advanced in the experiment in Krojczyn. Thus, in that experiment, the first fruit harvest was in 2012. It can therefore be assumed that the plants in that case produced a sufficient amount of plant biomass, ensuring enough water for the formation of fruit in the initial blooming plants. In Kosuty, the transformation from the vegetative to the generative phase, i.e. the first fruiting, was delayed by about half of one season.

Of the two experimental fields evaluated, the better one for cranberry fruiting was the field on a very sandy light soil with low organic matter content and low $\mathrm{pH}$. The fruit yields of the three cranberry cultivars varied in subsequent years. In 2014, in Krojczyn, there was a noteworthy increase in the yielding of the cultivar Stevens and decreased yields of the cultivars Pilgrim and Ben Lear. In the same year, in Kosuty, increased fruiting of the cultivar Pilgrim and reduced yields of 'Stevens' and 'Ben Lear' were observed. The final total yield for the fruiting seasons indicates that the most productive cultivars were Stevens in Krojczyn and Pilgrim in Kosuty. The reasons for the decline in fruiting in 2014 may be explained by the tendency of cranberry plants to bear fruit biennially, as reported by Strike et al. (1991) and Roper et al. (1993), and also mentioned by De Vetter et al. (2015). At the same time, some thermal disturbances may have been responsible (DeMoraville et al. 1996), because of an unexpected local thermal shock caused by decreasing temperatures from the 10th/20th of May partially limiting the blooming of cranberry plants. It happened when the flowers were between the phases of hook to blooming; only about $30 \%$ of the flowers bloomed in full. In this regard, the yielding of the cultivar Stevens is noteworthy in that year as well as in the previous year. At the same time, $B W$ reached the highest values for subsequent years of the experiment carried out in Krojczyn.

The value $c_{i}$ is an aggregate measure of the contribution of each component to the variability in yield that simultaneously takes into account component variability (variance) and relations among components (covariance). The absolute values of $c_{i}$ indicate that higher yield variability was affected mainly by location and year of cultivation (Fig. 1 C, D). Cultivar variability in the yield was markedly lower (Fig. 1 B). Looking at the studies taken together (Fig. 1 A), all yield components made positive contributions to cranberry yield, but mainly $N U / m^{2}$ followed by $B S$ and $F I$. Our data are generally consistent with previous studies. It is generally recognized that fruit set and the number of fruiting uprights are the main components of yield responsible for its variation (Eaton and Kyte 1978, Baumann and Eaton 1986). The major contribution to explain yield variability by $N U /$ $m^{2}$ was found earlier by Pelletier et al. (2015). The authors explained this phenomenon as yield determination by bud initiation during the year 

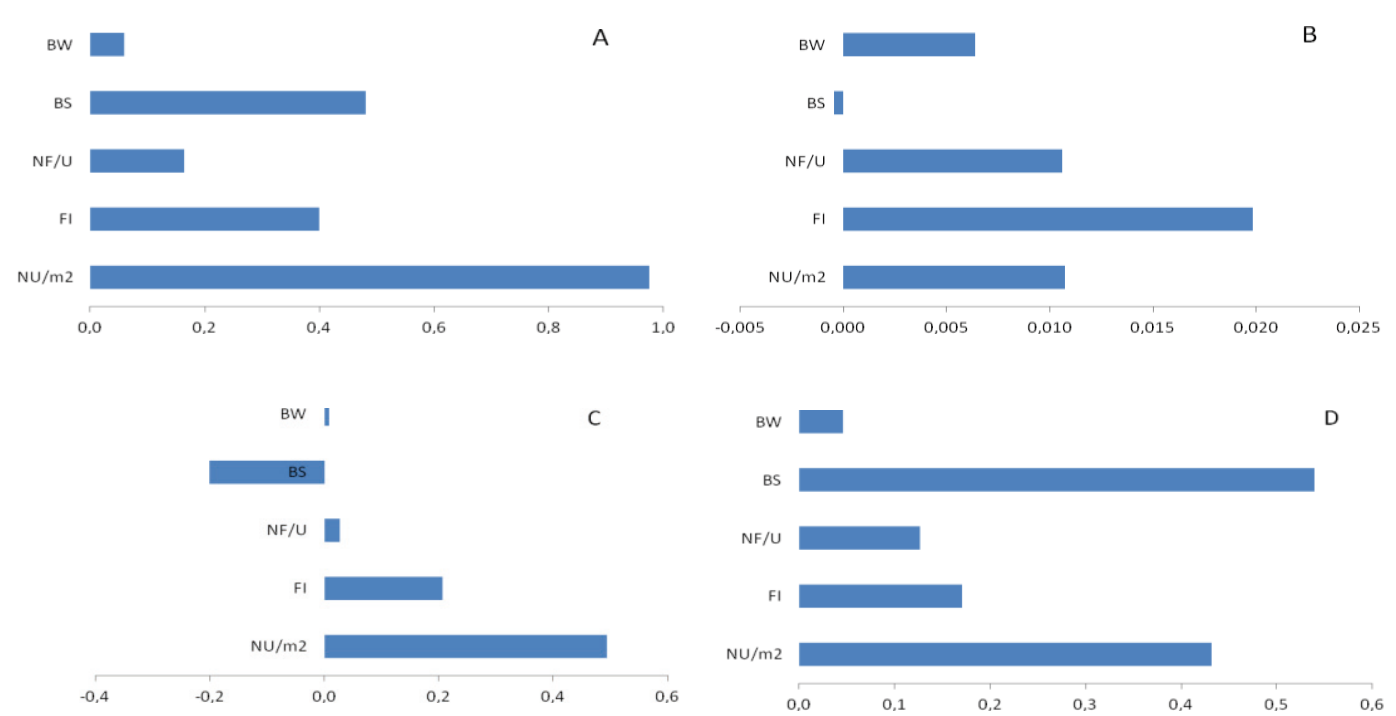

Figure 1. Contributions $\left(C_{i}\right.$ - values) of components to the variability of cranberry yield analysed using a multivariate mixed model (A - calculated across location $\times$ year $\times$ cultivar, B - effect of cultivar, $\mathrm{C}-$ effect of year, D - effect of location). $B W$ - individual berry weight; $B S$ - fruit set $\left(N B / m^{2}: N F / m^{2}\right) ; N F / U$ - number of flowers per upright; FIflowering index $\left(\mathrm{NFU} / \mathrm{m}^{2}: N U / \mathrm{m}^{2}\right) ; N U / \mathrm{m}^{2}$ - number of uprights per square meter

prior to sampling. Data concerning yield variability caused by the location of the experiment (Fig. 1 D) showed a greater role of $B S$ in yield determination. This suggests that different soil conditions at both locations markedly influenced berry set. The yield variability affected by the years of the experiment showed that $B S$ has a negative $c_{i}$ value, indicating a high compensation of this component by other components, mainly $\mathrm{NU} / \mathrm{m}^{2}$. The increment of the $\mathrm{NU} / \mathrm{m}^{2}$ across years caused decreasing $B S$ (negative covariance), which implies a negative $c_{i}$ value. A similar situation occurred in yield variability caused by differences among the tested cultivars, but to a lesser extent. Component compensation involved with $B S$ and $N U / \mathrm{m}^{2}$ has been previously described in cranberry (Eaton and Kyte 1978, Elle 1996, DeVetter et al. 2015). This phenomenon is a demonstration of the great plasticity of yield components in building gross yield.

\section{CONCLUSIONS}

1. The development of cranberry plants from rooted cuttings to the fruiting stage was more effective on a sandy soil with a low $\mathrm{pH}$ and low organic matter content, rather than on a sandy-loam soil with both higher $\mathrm{pH}$ and organic matter.

2. The study revealed that the number of uprights per $\mathrm{m}^{2}\left(N U / \mathrm{m}^{2}\right)$, floral induction $(F I)$, and berry set $(B S)$ played a key role in yield formation on the young cranberry plantation.

3. The acidification of the water used to irrigate plants on the sandy-loam soil with a higher $\mathrm{pH}$ contributed to the lowering of soil $\mathrm{pH}$. Cranberry plants respond favourably to this treatment.

\section{ACKNOWLEDGEMENT}

This research was financed by the National Science Centre, Poland (Grant NN 310732540), for which we are sincerely grateful. The authors wish to acknowledge the contribution of the Research Institute of Horticulture staff, particularly MSc Teresa Stępień, who conducted the analyses of the soil and plant samples.

\section{FUNDING}

Source of the presented research and manuscript: National Science Centre, Krakow, Poland, Grant NN 310732540.

\section{AUTHOR CONTRIBUTIONS}

S.E. - author and coordinator of the project as well as the first author manuscript; M.R. - author of the sophisticated statistical method and interpretation of the statistical results; K.B. - designer of the experimental field, biometrical measurements in the field, juxtaposition of collected results, basic statistical elaboration of experiment results; S.K. - propagation and preparation of hardwood rooted cranberry seedlings; B.H. - field observations of plant growth and development; S.-P.L. - preparation of the description of the results and discussion as well as editing of the text; D.E. - specific laboratory 
measurement description of the results; E.E. professional consulting.

\section{CONFLICT OF INTEREST}

Authors declare no conflict of interest.

\section{REFERENCES}

Avorn J., Monane M., Gurwitz J.H., Glynn R.J., Chodonovskiv I., Lipsitz L.A., 1994. Reduction of bacteriuria and pyuria after ingestion of cranberry and blueberry juices. JAMA 271: 751-754.

Baumann T.E., Eaton G.W., 1986. Competition among berries on the cranberry upright. J. Am. Soc. Horti Sci. 111: 869-872.

Benedycka Z., Bieniek A., Kawecki Z., 2005. Initial studies on the yield and quality of fruit of 4 varieties of cranberry Vaccinum macrocarpon Ait. in case of fertilization of the plants with urea phosphate. Płodowodstwo 17(2): 355-360.

Bretz F., Hothorn T., Westfall P., 2011. Multiple Comparisons Using R. CRC Press, Boca Raton, FL, USA.

Davenport J.R., DeMoranville C.J., 1993. A survey of several soil and physical characteristics of cultivated cranberry bogs in North America. Commun. Soil Sci. Plant Anal. 24(13-14): 1769-1773.

Davenport J.R., DeMoranville C.J., Hart J., Kumidini S., Patten K., Poole A., Roper T., 2003 Spatial and temporal variability of cranberry soil $\mathrm{pH}$. Acta Hort. 626: 323-336.

DeMoraville C.J., Patten K., Roper T.R., Strike B.C., Vorsa N., Poole A.P., 1996. Fruit mass development in three cranberry cultivars and five production regions. J. Am. Soc. Hort. Sci. 12(4): 680-685.

DeMoraville C.J., 2006. Cranberry best management practice adoption and conservation farm planning in Massachusetts. HortTechnology 16(3): 393-397.

DeVetter L., Colquhoun J., Zalapa J., Harbut R., 2015. Yield estimation in commercial system using physiological, environmental, and genetic variables. Sci. Hort. 190: 83-93.

Eaton G.W., Kyte T.R., 1978. Yield component analysis in the cranberry. J. Am. Soc. Hort. Sci. 103: 578583.

ElLE E., 1996. Reproductive trade-offs in genetically distinct clones of Vaccinium macrocarpon, the American cranberry. Oecologia 107: 61-70.

Food AND Agriculture Organization of the United Nations (FAO), FAOSTAT: Cranberries, 2012. Available online at http://faostat.fao.org/site/339/ default.aspx; cited on 18 Nov 2014.

Howell A.B., Reed J.D., Krueger C.G., Winterbottom R., Cunningham D.G., Leahy M., 2005. A-type cranberry proanthocyanidins and uropathogenic bacterial anti-adhesion activity. Phytochem. 66: 2282-2291.

Howell A.B., 2009. Update on health benefits of cranberry and blueberry. Acta Hort. 810: 779784.

KACZMARSKA E., 2009. Growth, flowering and yielding of six American cranberry (Vaccinium macrocarpon Ait.) cultivars. Acta Sci. Pol., Hortorum Cultus 8(4): 35-44.

Karczmarczyk S., Zbieć I., 1998a. Possibility of cultivating cranberries in Poland. Part I. Cultivation measures. Folia Univ. Agric. Stetin., Agricultura 69: 37-42.

Karczmarczyk S., Zbieć I., 1998b. Possibility of cultivating cranberries in Poland. Part II. Cranberry fruit usage. Folia Univ. Agric. Stetin., Agricultura 69: 43-46.

Krzewińska D., Borkowska D, Treder W., TryngielGAĆ A., 2008. Effect of some cultural practices on growth and yield of cranberry (Vaccinium macrocarpon Ait.): preliminary study. Proc. Int. Sci. Conf. "Sustainable Fruit Growing: From Plant To Product”, 28-31 May, Jūrmala-Dobele, Latvia, 198206.

Miller S., Scalzo J., Boldingh H., 2009. Cranberry cultivars for the New Zealand Industry. Acta Hortic. 810: 199-204.

Pelletier V., Gallichand J., Caron J., Jutras S., Marchand S., 2015. Critical irrigation threshold and cranberry yield components. Agric. Water Manag. 148: 106-112.

PiePHO H.P., 1995. A simple procedure for yield component analysis. Euphytica 84: 43-48.

Pinheiro J.C., Bates D.M., 2000. Mixed-Effects Models in $\mathrm{S}$ and S-PLUS. Springer-Verlag, New York, USA.

Poole A., Hart J., Righetti T., Strike B., 1997. Nutrient Management Guide. Cranberries. Oregon State Extention Service. EM 8672: 55.

R Development Core Team 2015. R: A Language and Environment for Statistical Computing. R Foundation for Statistical Computing, Vienna, Austria.

Roper T.R., Patten K.D., DeMoraville C.J., Davenport J.R., Strik R.C., Poole A.P., 1993. Fruiting of cranberry uprights reduces fruiting the following year. HortScience 28(3): 228.

SChafer J.L., Yucel R.M., 2002. Computational strategies for multivariate linear mixed- effects models with missing values. J. Comp. Graph. Stat. 11: 421-442.

Shmuely H., Burger O., Neeman I., Yahav J, Samra Z., NIV Y., et al., 2004. Susceptibility of Helicobacter pylori isolates to the antiadhesion activity of a highmolecular-weight constituent of cranberry. Diagn. Microbiol. Infect. Dis. 50(4): 231-235.

Stang E.J., 1997. The emerging cranberry industry in Chile. Acta Hort. 446: 159-163. 
Strike B.C., Roper T.R., DeMoraville C.J., Davenport J.R., Poole A.P., 1991. Cultivar and growing region influence return bloom in cranberry uprights. HortScience 26(11): 1366-1367.

Van den Heuvel J.E., DeMoraville C.J., 2009. Competition between vegetative and reproductive growth of cranberry. HortScience 44(2): 322-327.
Vatten D.A., Lin Y.T., Ghaedian R., Shetty K., 2005. Cranberry synergies for dietary management of Helicobacter pylori infections. Process Biochem. 40(5): 1583-1592.

Received October 29, 2015; accepted March 22, 2016 